\title{
Description and Capabilities of the Large-Scale In Situ Vitrification Process
}

J. L. Buelt

J. G. Carter

January 1986

Prepared for the U.S. Department of Energy under Contract DE-AC06-76RLO 1830

Pacific Northwest Laboratory Operated for the U.S. Department of Energy by Battelle Memorial Institute 


\title{
DISCLAIMER
}

This report was prepared as an account of work sponsored by an agency of the United States Government. Neither the United States Government nor any agency thereof, nor any of their employees, makes any warranty, express or implied, or assumes any legal liability or responsibility for the accuracy, completeness, or usefulness of any information, apparatus, product, or process disclosed, or represents that its use would not infringe privately owned rights. Reference herein to any specific commercial product, process, or service by trade name, trademark, manufacturer, or otherwise, does not necessarily constitute or imply its endorsement, recommendation, or favoring by the United States Government or any agency thereof. The views and opinions of authors expressed herein do not necessarily state or reflect those of the United States Government or any agency thereof.

\author{
PACIFIC NORTHWEST LABORATORY \\ operated by \\ BATTELLE \\ for the \\ UNITED STATES DEPARTMENT OF ENERGY \\ under Contract DE-AC06-76RLO 1830
}

\begin{tabular}{|c|c|}
\hline \multicolumn{2}{|c|}{ Printed in the United States of America } \\
\hline \multicolumn{2}{|c|}{ Available from } \\
\hline \multirow{2}{*}{\multicolumn{2}{|c|}{$\begin{array}{l}\text { National Technical Information Service } \\
\text { United States Department of Commerce }\end{array}$}} \\
\hline & \\
\hline \multicolumn{2}{|c|}{5285 Port Royal Road } \\
\hline \multicolumn{2}{|c|}{ Springfield, Virginia 22161} \\
\hline \multirow{2}{*}{\multicolumn{2}{|c|}{$\begin{array}{l}\text { NTIS Price Codes } \\
\text { Microfiche A01 }\end{array}$}} \\
\hline & \\
\hline \multicolumn{2}{|c|}{ Printed Copy } \\
\hline & \\
\hline Pages & Codes \\
\hline $001-025$ & A02 \\
\hline 026-050 & $\mathrm{A} 03$ \\
\hline 051-075 & A04 \\
\hline $076-100$ & A05 \\
\hline $101-125$ & $A 06$ \\
\hline $126-150$ & A07 \\
\hline 151-175 & A08 \\
\hline $176-200$ & $A 09$ \\
\hline $201-225$ & A010 \\
\hline $226-250$ & A011 \\
\hline $251-275$ & A012 \\
\hline $276-300$ & A013 \\
\hline
\end{tabular}


PNL -5738

DESCRIPTION AND CAPABILITIES OF THE LARGE-SCALE

IN SITU VITRIFICATION PROCESS

J. L. Buelt

J. G. Carter

January 1986

Prepared for

the U.S. Department of Energy

under Contract DE-ACO6-76RLO 1830

Pacific Northwest Laboratory

Richland, Washington 99352 


\section{SUMMARY}

An emerging thermal treatment process known as in situ vitrification is being developed to immobilize selected portions of radioactively contaminated soils. The process is a permanent remedial action that destroys solid and liquid organic contaminants and incorporates radionuclides and heavy metals into a glass and crystalline form. The process's flexibility in design and broad capabilities make it potentially adaptable to mixed and chemical wastes, as we11. The process consists of an electrical power system for vitrifying contaminated soil, a hood to contain gaseous effluents, an off-gas treatment system, an off-gas cooling system, and a process control station. The process is mounted in three transportable trailers that can be easily moved from site to site. The process is capable of treating contaminated soils at least $13 \mathrm{~m}$ deep. The system components are designed to accommodate waste inclusions in the soil such as metals, combustibles, and large voids. Selectively applied to the more troublesome radioactively contaminated soils, in situ vitrification provides a potentially useful and permanent tool for remedial action. 


\section{CONTENTS}

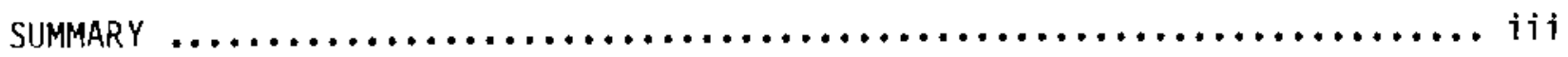

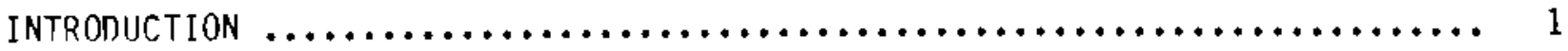

PROCESS DESCRIPTION $\ldots \ldots \ldots \ldots \ldots \ldots \ldots \ldots \ldots \ldots \ldots \ldots \ldots \ldots \ldots \ldots \ldots \ldots \ldots \ldots$

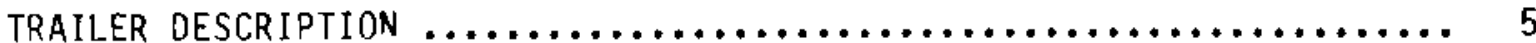

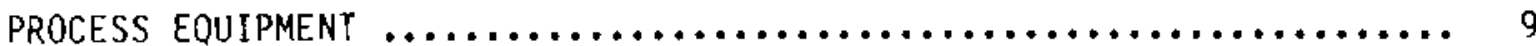

Electricat Power Supply $\ldots \ldots \ldots \ldots \ldots \ldots \ldots \ldots \ldots \ldots \ldots \ldots \ldots \ldots . \ldots . \ldots$

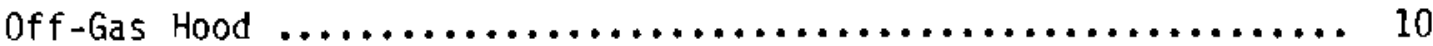

off-Gas Treatment System .......................... 10

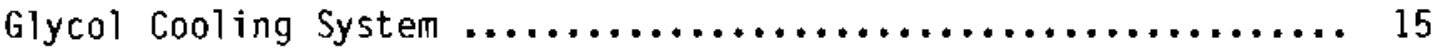

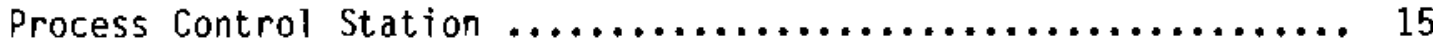

Off-Gas Support Equipment $\ldots \ldots \ldots \ldots \ldots \ldots \ldots \ldots \ldots \ldots \ldots \ldots \ldots$

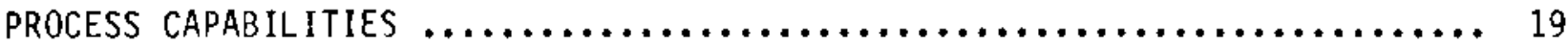

GEOMETRIC FLEXIBILITY $\ldots \ldots \ldots \ldots \ldots \ldots \ldots \ldots \ldots \ldots \ldots \ldots \ldots \ldots \ldots \ldots \ldots \ldots$

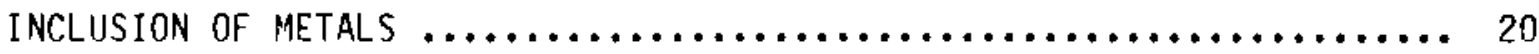

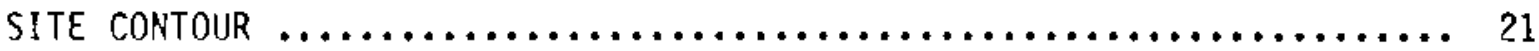

OFF-GAS CONTAINMENT $\ldots \ldots \ldots \ldots \ldots \ldots \ldots \ldots \ldots \ldots \ldots \ldots \ldots \ldots \ldots \ldots \ldots \ldots \ldots$

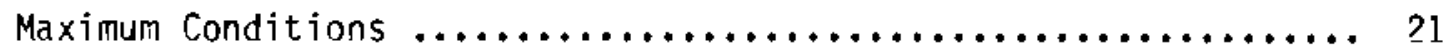

Bases for Maximum Conditions ....................... 22

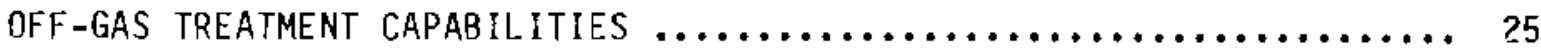

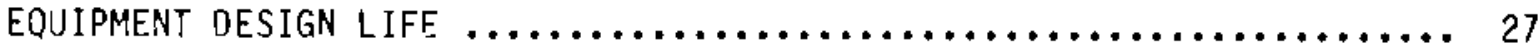

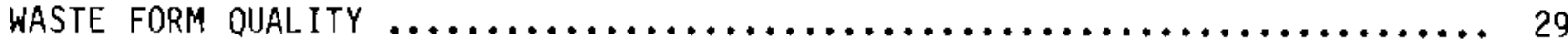

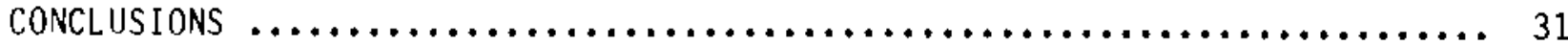

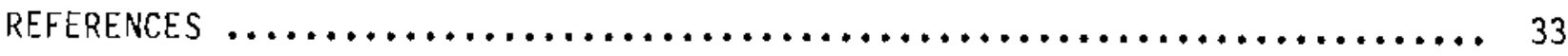




\section{FIGURES}

1 The Process of In Situ Vitrification $\ldots \ldots \ldots \ldots \ldots \ldots \ldots \ldots \ldots \ldots \ldots \ldots$ ?

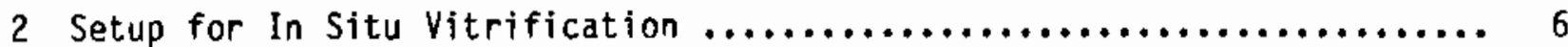

3 Process Trailers for the Large-Scale In Situ Vitrification Unit ....... 7

4 Off-Gas Trailer ....................................... 8

50 ff-Gas Hood for Large-Scale In Situ Vitrification $\ldots \ldots \ldots \ldots \ldots \ldots \ldots . \ldots 11$

6 Off-Gas System for Large-Scale In Situ Vitrification ............... 12

7 Attainable Vitrification Depths $\ldots \ldots \ldots \ldots \ldots \ldots \ldots \ldots \ldots \ldots \ldots \ldots \ldots \ldots \ldots$

8 Gaseous Release Rate for Single Combustible volumes ................ 24

\section{TABLES}

1 Testing Units for Developing In Situ Vitrification Technology ....... 3

2 Energy and Mass Balance of Off-Gas Treatment System .............. 13

3. Comparison of Stack Effluent Concentrations with Environmental Requi rements 


\section{INTRODUCTION}

As the management of radioactive and hazardous materials gains increased attention in the United States, new and innovative technologies are being sought to properly dispose the wastes permanently. Included in this search are remedial action techniques for soils contaminated with radioactive and chemical elements. To illustrate the need for improved technologies, transuranic wastes previously disposed from past national defense activities at numerous locations throughout the U.S. may require enhanced stabilization for permanent disposal. In addition, the U.S. Environmental Protection Agency has issued its proposed National Priorities List of 850 hazardous waste sites requiring remedial action (Hazardous Materials Control Research Institute 1984). Of these sites, many contain soils contaminated with heavy metals, PCBs, benzene, toluene, and other organics (World Information Systems 1982). Many sites may require remedial action techniques beyond the present state of the art.

Pacific Northwest Laboratory (PNL) is developing a remedial action process for contaminated soils that could be potentially significant in its application to this national concern. Although the process is presently being developed for radioactively contaminated soils, with some additional development it can be applied to chemically hazardous waste sites. The process, in situ vitrification (ISV), is being developed for the U.S. Department of Energy.

In situ vitrification is a thermal treatment process that converts contaminated soil into a chemically inert and stable glass and crystalline product. Figure 1 illustrates how the process operates. A square array of four molybdenum electrodes are inserted into the ground to the desired treatment depth. Because soil is not electrically conductive once the moisture has been driven off, a conductive mixture of flaked graphite and glass frit is placed among the electrodes to act as the conductive starter path. An electrical potential is applied to the electrodes, which establishes an electrical current in the starter path. The resultant power heats the starter path and surrounding soil up to $2000^{\circ} \mathrm{C}$, well above the initial melting temperatures of 1100 to $1400^{\circ} \mathrm{C}$. The graphite starter path is eventually consumed by oxidation, and the current is transferred to the molten soil, which is now electrically 


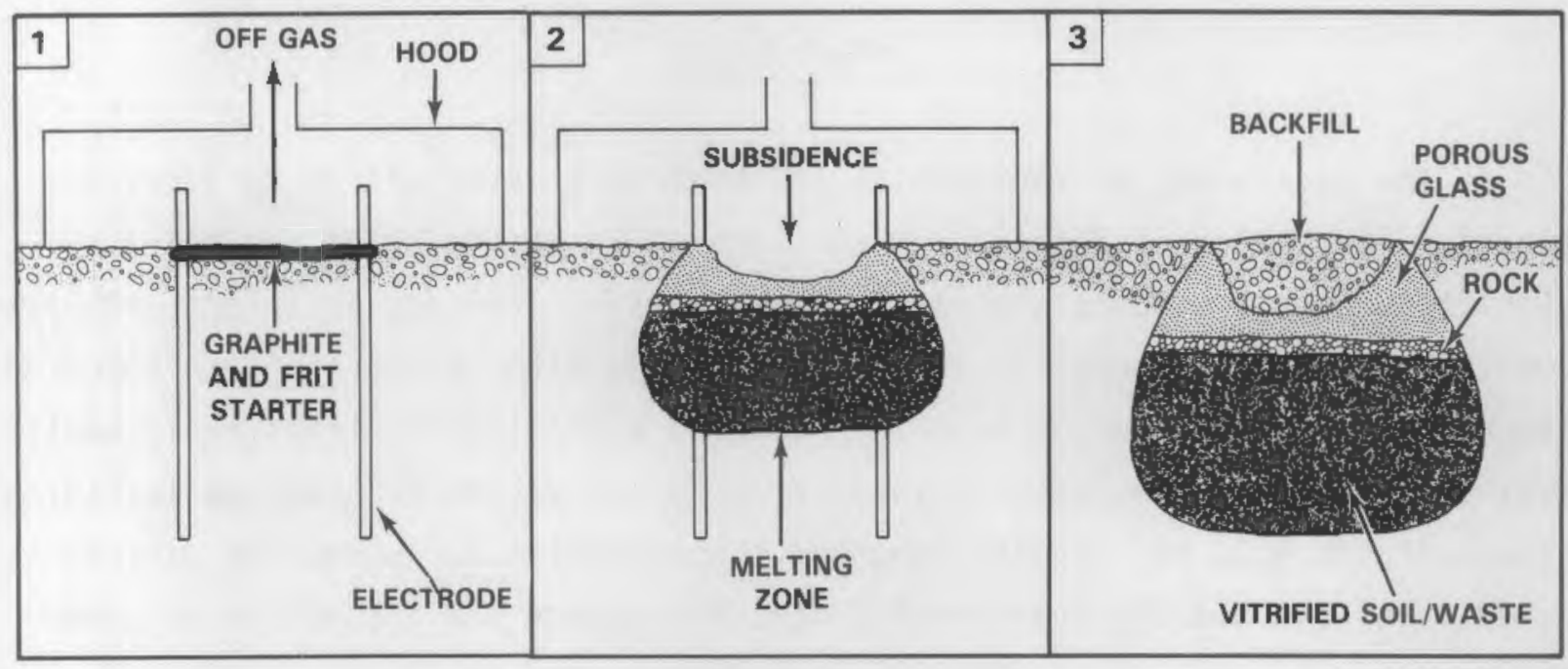

FIGURE 1. The Process of In Situ Vitrification

conductive. As the molten or vitrified zone grows, it incorporates nonvolatile hazardous elements, such as heavy metals, and destroys organic components by pyrolysis. The pyrolyzed byproducts migrate to the surface of the vitrified zone where they combust in the presence of oxygen. A stainless steel hood placed over the area being vitrified directs the gaseous effluents to an offgas treatment system.

Pacific Northwest Laboratory began developing ISV technology in 1980 under the support of the U.S. Department of Energy. Since that time numerous experimental tests under a variety of conditions and waste types have been conducted (Oma 1983, Timmerman and Oma 1984, Timmerman et a1. 1983). Table 1 describes the different scales of testing units that PNL used in developing ISV technology. The successful results of the 36 engineering- and pilot-scale tests have proven the feasibility of the process. Also, economics studies have indicated that tremendous economies of scale are attainable with the ISV process (Oma 1983). This led to the commitment to design, fabricate, and test a large-scale prototype. Successful testing of the large-scale version of the ISV process will provide the developmental information necessary to apply the process to radioactively contaminated soils on a production scale.

The large-scale process equipment has been fabricated and installed, and testing with nonradioactive mockups of actual large-scale contaminated sites is 
TABLE 1. Testing Units for Developing In Situ Vitrification Technology

\begin{tabular}{|c|c|c|c|}
\hline Equipment Size & $\begin{array}{l}\text { Electrode } \\
\text { Separation }\end{array}$ & $\begin{array}{l}\text { Block } \\
\text { Size }\end{array}$ & $\begin{array}{c}\text { Tests } \\
\text { Completed } \\
\end{array}$ \\
\hline Engineering Scale & $0.23-0.36 \mathrm{~m}$ & $0.05-1.0 \mathrm{t}$ & 24 \\
\hline Pilot Scale & $1.2 \mathrm{~m}$ & $10-50 t$ & 12 \\
\hline Large Scale & $3.5-5.5 m$ & $400-800 t$ & 3 \\
\hline
\end{tabular}

currently underway. This report presents an in-depth description of the largescale process and its capabilities. Pacific Northwest Laboratory recognizes that ISV is not the solution to all radioactive and hazardous waste management problems, but judiciously applied, ISV can offer technical and economic improvements to state-of-the-art remedial action technology. With an understanding of the process design and functions, the hazardous materials manager can make a sound judgment about the applicability of ISV to site-specific disposal problems. 


\section{PROCESS DESCRIPTION}

The large-scale process equipment for in situ vitrification is depicted in Figure 2. The process immobilizes contaminated soil and isolates it from the surrounding environment. Controlled electrical power is distributed to the electrodes, and special equipment contains and treats the gaseous effluents. The process equipment required to perform these functions can be described most easily by dividing it into six major components:

- electrical power supply

- off-gas hood

- off-gas treatment system

- glycol cooling system

- process control station

- off-gas support equipment.

Except for the off-gas hood, all the components are contained in three transportable trailers shown in Figure 3. They consist of an off-gas trailer, a process control trailer, and a support trailer. All three trailers are mounted on wheels sufficient to accommodate a move to any site over a compacted ground surface. The off-gas hood and off-gas line, which are installed on the site for collection of gaseous effluents, are dismantled and placed on a flatbed trailer for transport. The effluents exhausted from the hood are cooled and treated in the off-gas treatment system. The entire process is monitored and controlled from the process control station.

\section{TRAILER DESCRIPTION}

The off-gas trailer is enclosed and contains an internal containment module. The containment module houses and isolates the off-gas treatment equipment in the off-gas trailer as shown in Figure 4. The containment module is a large glovebox constructed primarily of stainless steel. It isolates operators from processing equipment, and protects them from being contaminated during an off-normal condition such as a leak in pressurized piping. The containment module was designed for handling radioactive contaminants and may not be necessary for treating chemically hazardous wastes. The containment 


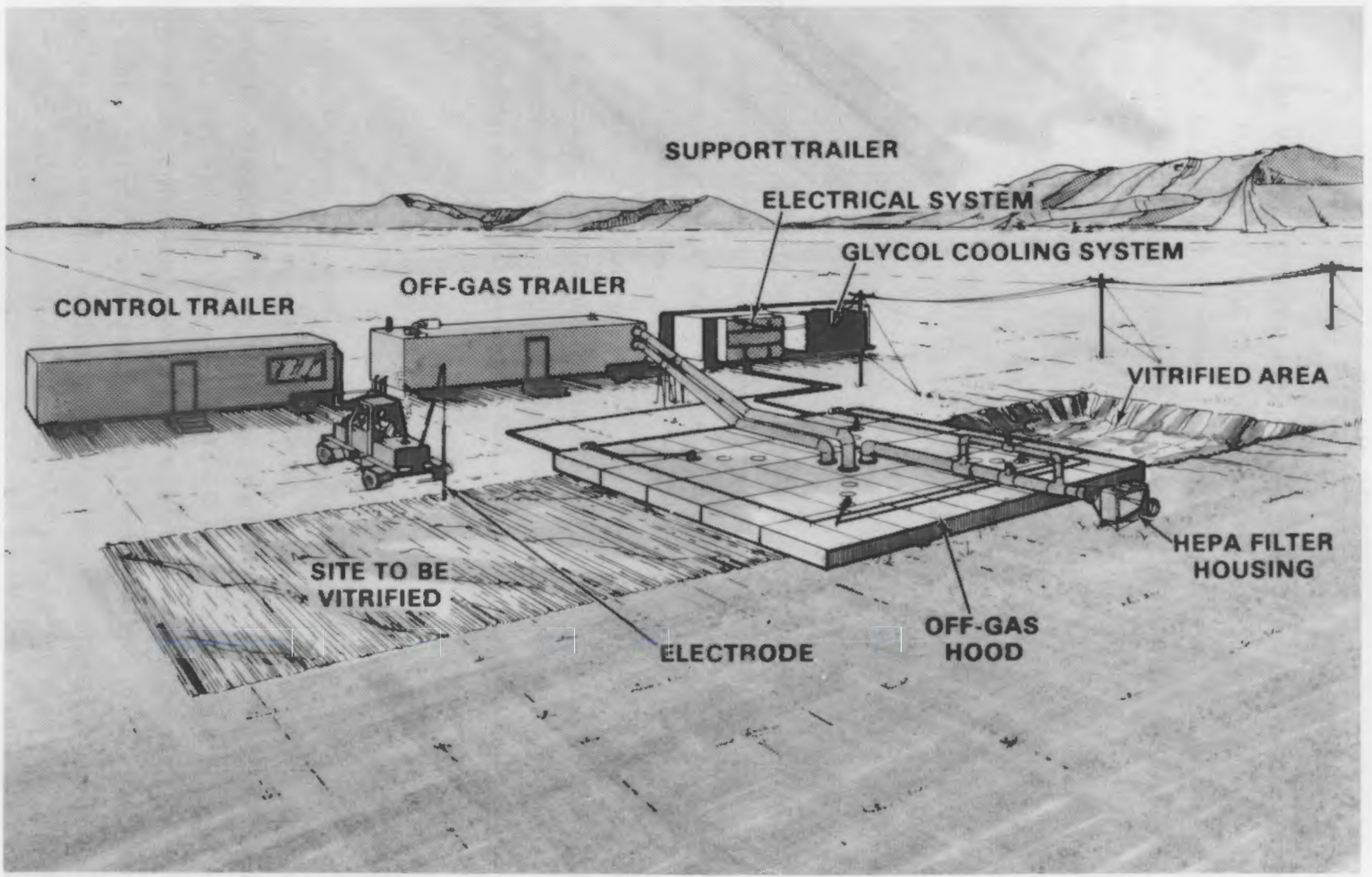

FIGURE 2. Setup for In Situ Vitrification 

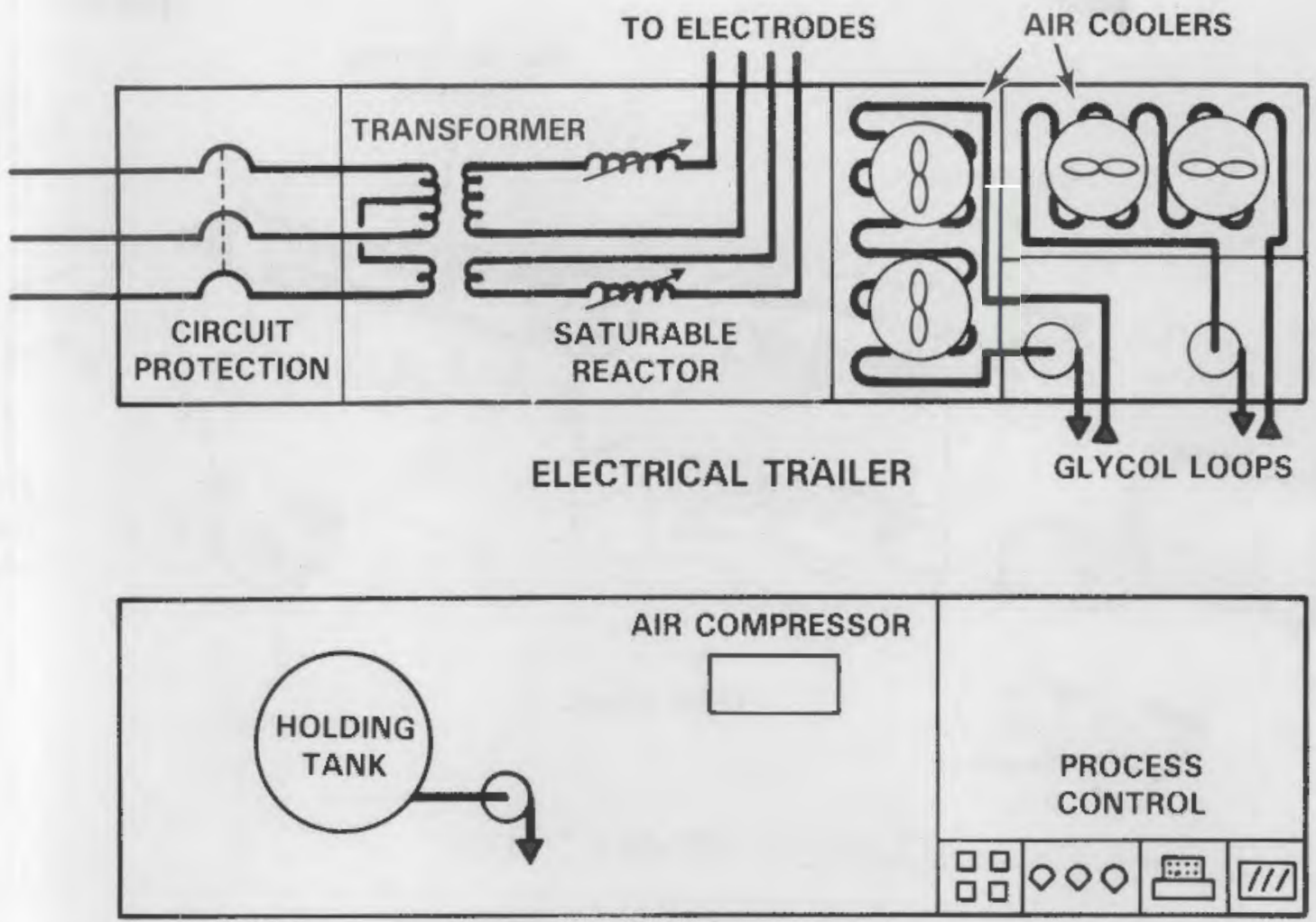

PROCESS CONTROL TRAILER

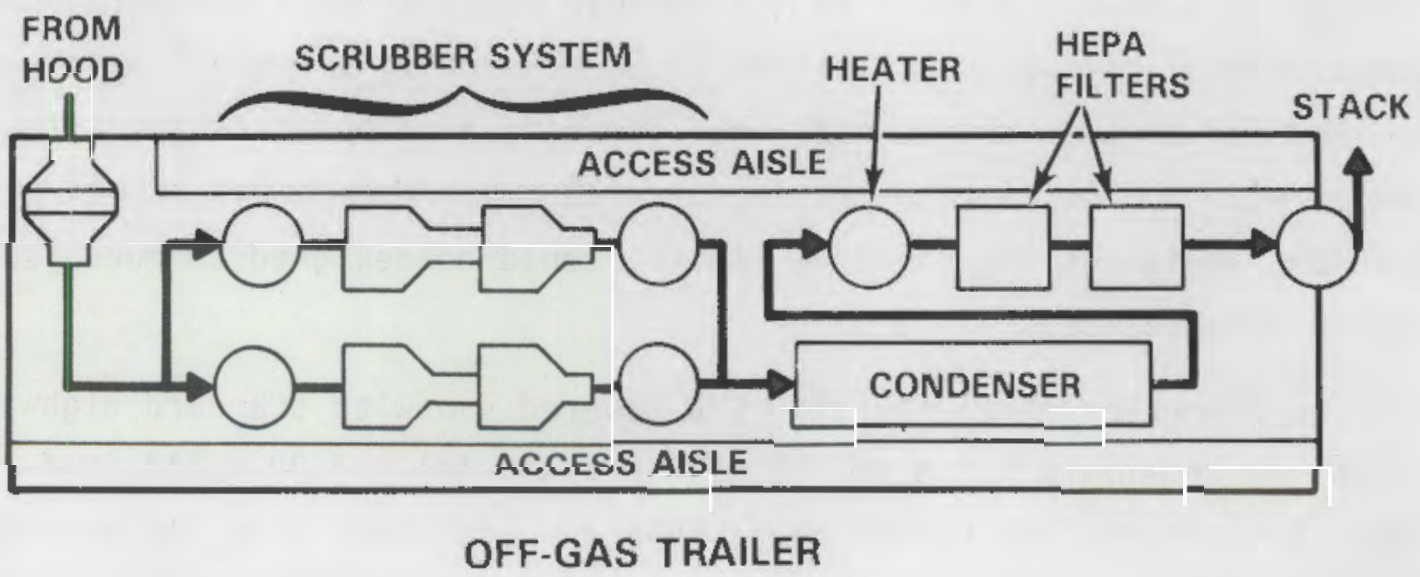

FIGURE 3. Process Trailers for the Large-Scale In Situ Vitrification Unit

module is vented by two independent blowers operated by either primary or emergency power and has high-efficiency particulate air (HEPA) filters at the entrance and exit. A slightly negative pressure $(1 \mathrm{~cm}$ of water) is maintained within the containment module relative to the aisles. The of $f$-gas trailer measures $3.6 \mathrm{~m}(12 \mathrm{ft})$ wide $\times 18.3 \mathrm{~m}(60 \mathrm{ft})$ long and weighs $55,000 \mathrm{~kg}$ 


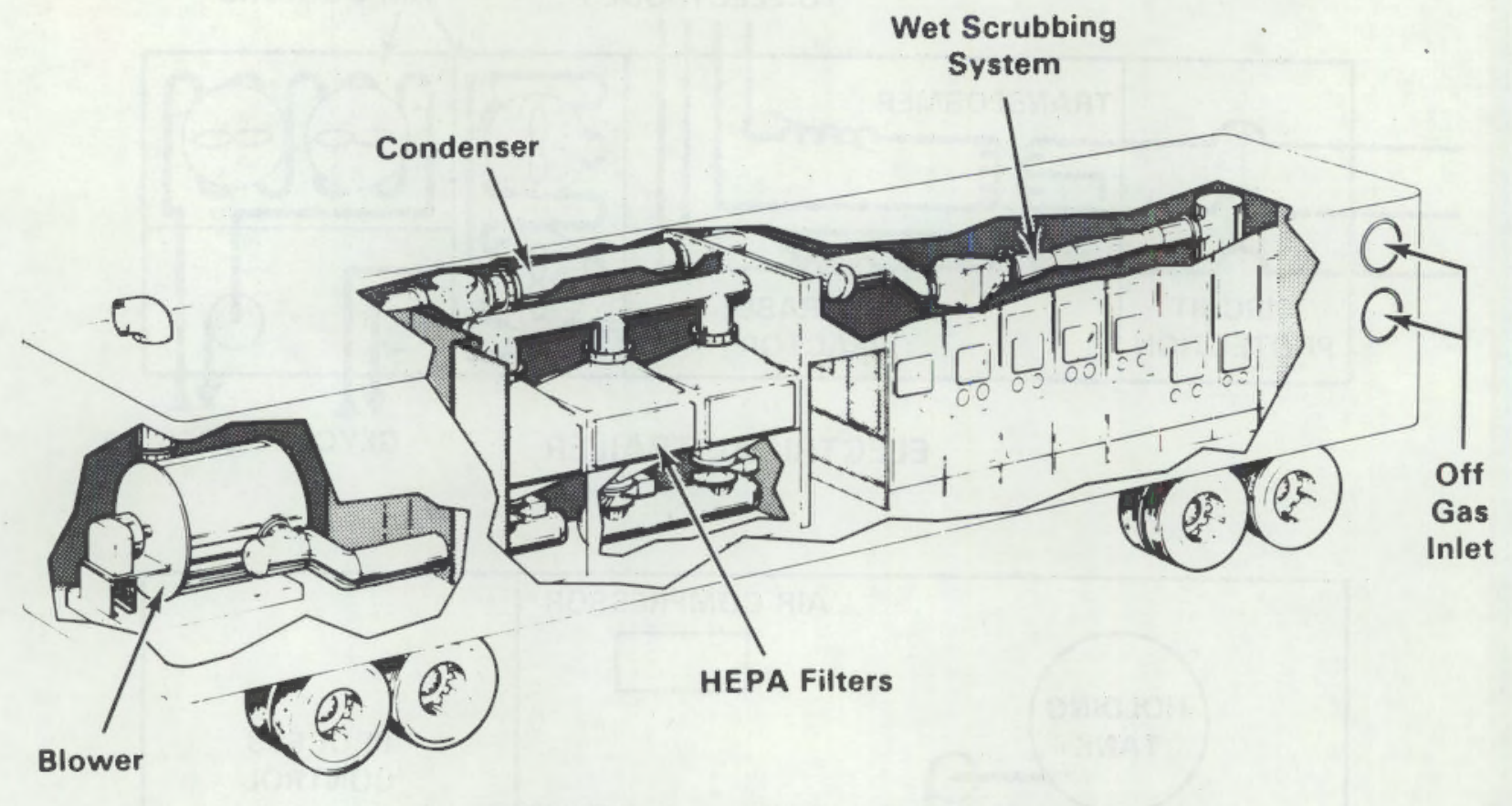

FIGURE 4. Off-Gas Trailer

$(121,000 \mathrm{lb})$. The maximum height of the off-gas trailer including the undercarriage is $4.32 \mathrm{~m}$ (14 ft, $2 \mathrm{in.}$ ). Because the trailer's dimensions and weight exceed federal highway restrictions (U.S. CFR 1984), a special permit is required for highway transportation. However, a decontamination of $f$-gas trailer with no containment module, or with other reductions in of $f$-gas treatment equipment for chemical wastes, could be designed to meet federal highway restrictions.

The process control trailer is a covered van with standard highway dimensions measuring $2.4 \mathrm{~m}(8 \mathrm{ft}) \times 13.7 \mathrm{~m}(45 \mathrm{ft}) \times 4.08 \mathrm{~m}(13 \mathrm{ft}-4-1 / 2 \mathrm{in.})$ high. All process monitoring operations are performed from the process control station located in this trailer. In addition, the trailer houses miscellaneous support equipment of the off-gas system. A soundproof wall exists between the support equipment and the process control equipment. Like the off-gas trailer, the control trailer is constructed of aluminum and painted steel walls that are insulated with a noncombustible material.

The support trailer houses the electrical power supply and glycol cooling system. A standard flat bed trailer, it measures $2.6 \mathrm{~m}(8.5 \mathrm{ft}) \times 14.6 \mathrm{~m}$ 
(48 ft) $\times 1.40 \mathrm{~m}(4 \mathrm{ft} 7.25 \mathrm{in.})$ high. Overall height with equipment mounted on the trailer is $4.1 \mathrm{~m}(13.6 \mathrm{ft})$. The trailer's total load capacity is $34,100 \mathrm{~kg}(75,000 \mathrm{lb})$.

Communication stations are established in each of the three trailers for operational control and safety. For example, an operator making an adjustment to a valve in the off-gas trailer can be in constant contact with the operator monitoring the process from the control trailer. Indoor and/or exterior lighting are provided on all three trailers. Outdoor electrical services are provided for air sampling and other support equipment. Power for all lighting and communication services is provided by a circuit that is independent from the electrode power supply.

\section{PROCESS EQUIPMENT}

The six major components of the large-scale ISV process--electrical power supply, off-gas hood, off-gas treatment system, glycol cooling system, process control station, and off-gas support equipment--are integrated to provide a flexible system capable of treating various contaminated soils and buried wastes. A description of individual features and capabilities of the major components follows.

\section{Electrical Power Supply}

The electrical power supply provides and regulates power to the electrodes. It is composed of a 3750-kVA power supply and $15-k V$ circuit protection switchgear.

Power is supplied to the electrodes from the 3750-kVA Scott-Tee power supply, which provides 14 different voltage taps. A Scott-Tee transformer converts three-phase power to a balanced two-phase system (Lazar 1977). Voltages are achievable from $4160 \mathrm{~V}$ to $440 \mathrm{~V}$ at an amperage from $450 \mathrm{~A}$ to 4000 A per electrode pair. A saturable reactor in series with the load controls power to the electrodes between voltage taps for maximum efficiency, safety, and control. The power supply measures $4.33 \mathrm{~m} \times 2.4 \mathrm{~m} \times 2.4 \mathrm{~m}$ high $(14.2 \mathrm{ft} \times 8 \mathrm{ft} \times 8 \mathrm{ft})$ and weighs approximately $27,000 \mathrm{~kg}(60,000 \mathrm{lb})$. 
Power to the 3750-kVA power supply can be interrupted by the 15-kV circuit protection switchgear located adjacent to the power supply. Power can be shut down at the switchgear or remotely from the control pane1. Power interruption to the electrode power supply will not interfere with power to the off-gas equipment. The switchgear measures $0.91 \mathrm{~m} \times 2.4 \mathrm{~m}$ long and can be serviced through removable side panels.

Off-Gas Hood

The hood (Figure 5) contains the gaseous effluents from the process, provides a confined area for combustion, and directs the effluents to the off-gas system. Because it supports the electrodes via insulators, the hood is grounded. It measures $12 \mathrm{~m}(40 \mathrm{ft}) \times 12 \mathrm{~m}(40 \mathrm{ft}) \times 1.8 \mathrm{~m}(6 \mathrm{ft}) \mathrm{high}$ and is supported by joists. A lifting device is located at each corner so that the assembled hood can be repositioned to a new nearby setting. The hood is constructed of 16-gauge stainless steel panels, bolted and gasketed together in a manner that relieves stresses due to nonuniform thermal expansion. The hood is sealed to the ground by a high-temperature flexible skirt, which is bolted around the hood's perimeter and covered with soil. The hood is connected to the off-gas trailer by two $40-\mathrm{cm}(16-\mathrm{in}$.$) off-gas lines (two are provided for$ redundancy). A 30-cm (12-in.) combustion air inlet and a pressure relief valve with high-temperature HEPA filters are annexed to the hood. The HEPA filters provide off-gas decontamination of particulates in the event of pressurization and backflow. The combustion air and off-gas flows are separated by a heat shield that extends below the hood's ceiling. The heat shield effectively directs combustion air toward the surface of the vitrification zone and keeps the hood-skin temperatures within the $550^{\circ} \mathrm{C}$ design criteria. Off-Gas Treatment System

The off-gas treatment system (Figure 6) cools, scrubs, and filters the gaseous effluents exhausted from the hood. Its primary components include: a gas cooler, two wet scrubber systems (tandem nozzle scrubbers and quenchers), two heat exchangers, two process scrub tanks, two scrub solution pumps, a condenser, three mist eliminators (vane separators), a heater, a HEPA filter 

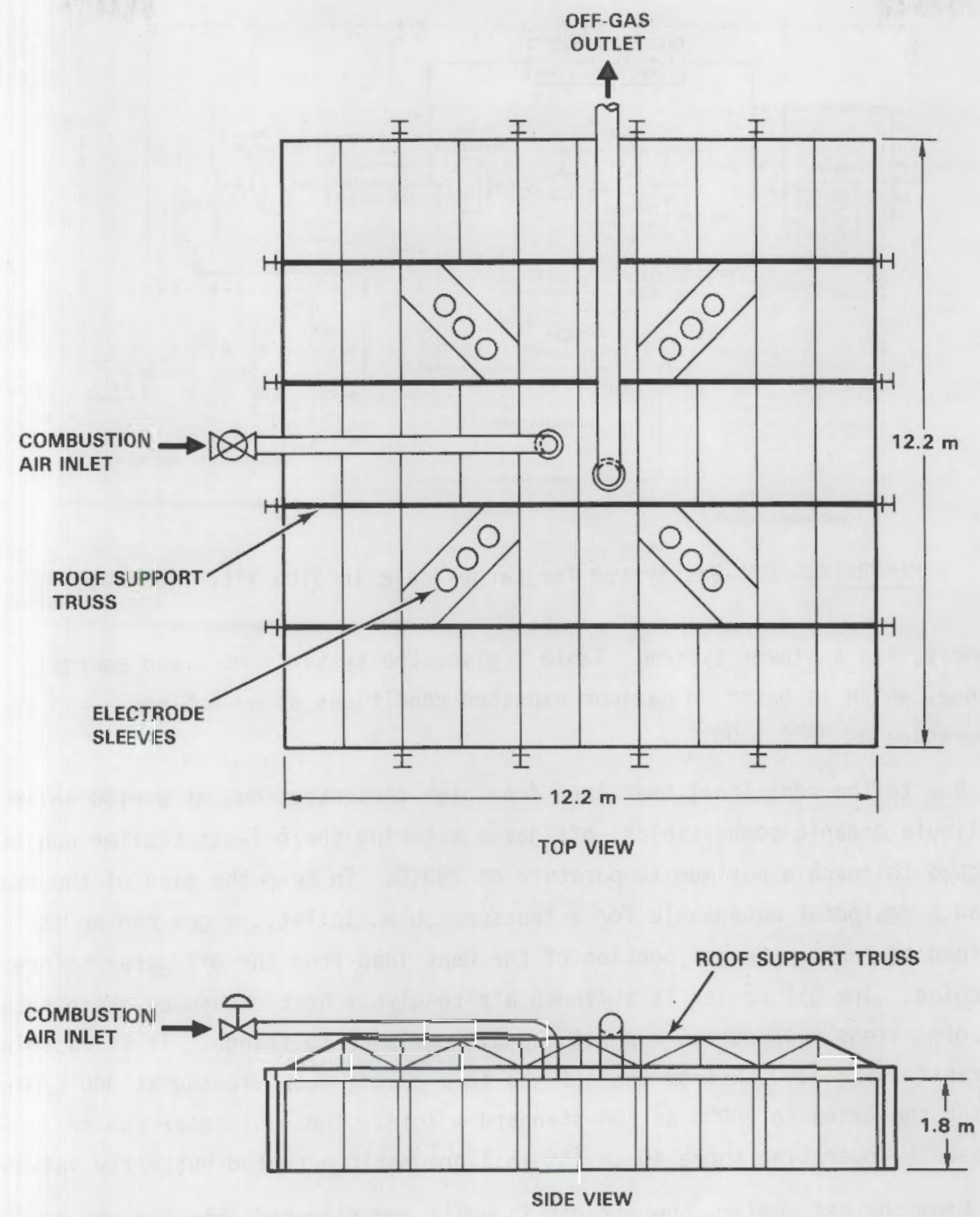

FIGURE 5. Off-Gas Hood for Large-Scale In Situ Vitrification 


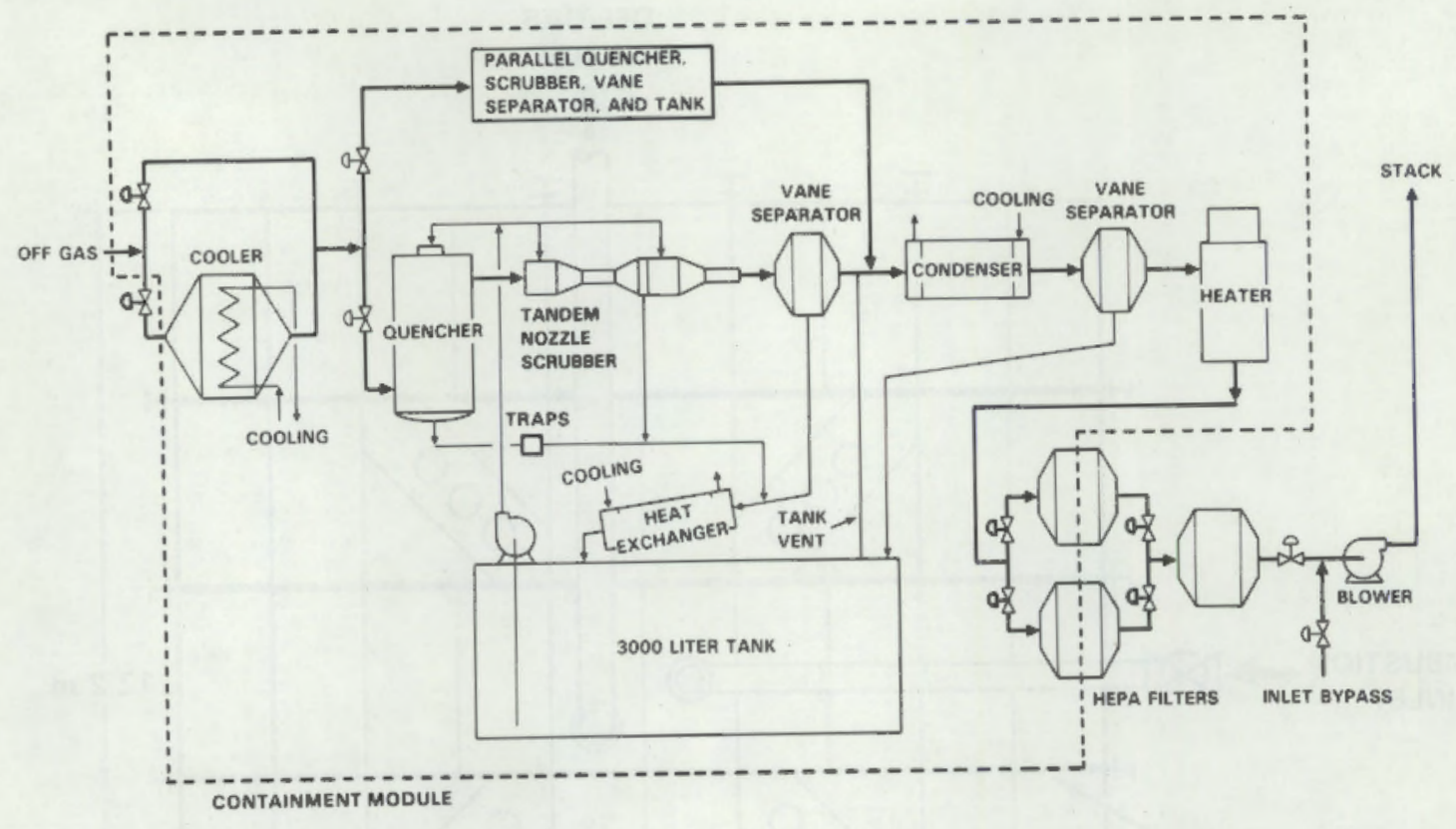

FIGURE 6. Off-Gas System for Large-Scale In Situ Vitrification

assembly, and a blower system. Table 2 gives the system's mass and energy balance, which is based on maximum expected conditions at an ambient temperature of $38^{\circ} \mathrm{C}\left(100^{\circ} \mathrm{F}\right)$.

Due to the additional heat load from high concentrations of buried solid and liquid organic combustibles, off gases entering the off-gas trailer can be expected to reach a maximum temperature of $750^{\circ} \mathrm{C}$. To keep the size of the heat exchange equipment manageable for a transportable facility, a gas cooler is provided to remove a major portion of the heat load from the of $f$ gases before quenching. The gas cooler is a finned air-to-glycol heat exchanger whose outside dimensions measure $1.5 \mathrm{~m} \times 1.5 \mathrm{~m} \times 1.3 \mathrm{~m}$ flange to flange. It is capable of transferring $1100 \mathrm{~kW}$ from the off gas to a glycol loop flowing at $340 \mathrm{~L} / \mathrm{min}$, cooling the gases to $300^{\circ} \mathrm{C}$ at 104 standard $\mathrm{m}^{3} / \mathrm{min}$. The gas cooler can be bypassed by operating three $40-\mathrm{cm}(16-\mathrm{in}$.) pneumatic actuated butterfly valves.

From the gas cooler, the off gas is split and directed into two wet scrubber systems operating in parallel. Two scrubbing systems provide an operating flow range between 30 and 104 standard $\mathrm{m}^{3} / \mathrm{min}$. Because scrubbing efficiency falls drastically with flow rate, two parallel systems are required for this range of flows. At flows less than 60 standard $\mathrm{m}^{3} / \mathrm{min}$, only one system will 
TABLE 2. Energy and Mass Balance of Of $f$-Gas Treatment System

\begin{tabular}{|c|c|c|c|}
\hline Equipment & Mass Flow & Temperature $\left({ }^{\circ} \mathrm{C}\right)$ & $\begin{array}{c}\text { Energy } \\
\text { Transfer } \\
\text { (kw) }\end{array}$ \\
\hline Gas cooler & $104(\mathrm{a})$ & $\begin{array}{r}750 \\
9 ?\end{array}$ & -1100 \\
\hline Quencher (each) & $52(a)$ & $\begin{array}{r}300 \\
52\end{array}$ & $\begin{array}{r}-271 \\
271\end{array}$ \\
\hline $\begin{array}{l}\text { Tander nozzle scrubber } \\
\text { (each) }\end{array}$ & $\begin{array}{r}59(\mathrm{a}) \\
121\end{array}$ & $\begin{array}{l}66 \\
52\end{array}$ & $\begin{array}{r}-68 \\
68\end{array}$ \\
\hline Vane separator (each) & $\begin{array}{r}57(\mathrm{a}) \\
121(\mathrm{~b})\end{array}$ & $\begin{array}{l}60 \\
60\end{array}$ & 0 \\
\hline Heat exchanger (each) & $178^{(b)}$ & $\begin{array}{l}60 \\
48\end{array}$ & $\begin{array}{r}-120 \\
120\end{array}$ \\
\hline $\begin{array}{l}\text { Process scrub tank } \\
\text { (each) }\end{array}$ & $178^{(b)}$ & 52 & 0 \\
\hline Condenser & $114(\mathrm{a})$ & $\begin{array}{l}60 \\
46\end{array}$ & $\begin{array}{r}-260 \\
260\end{array}$ \\
\hline Mist eliminator & $104(\mathrm{a})$ & $\begin{array}{l}52 \\
52\end{array}$ & \\
\hline $\begin{array}{l}\text { Heater } \\
\text { HEPA filter assembly } \\
\text { Blower system }\end{array}$ & $\begin{array}{l}104(a) \\
104(a) \\
104(a)\end{array}$ & $\begin{array}{l}52 \\
77 \\
17\end{array}$ & 56 \\
\hline $\begin{array}{l}\text { Glycol system A } \\
\text { Glycol cooling system B }\end{array}$ & $\begin{array}{r}340^{(c)} \\
1500^{(c)}\end{array}$ & $\begin{array}{r}133 \\
52\end{array}$ & $\begin{array}{r}-1100 \\
-500\end{array}$ \\
\hline
\end{tabular}

operate. The dual scrub system also provides redundancy in the event of single component failure. Each system, which measures $5.8 \mathrm{~m}$ flange to flange, is composed of a quench tower, a tandem nozzle scrubber, and a vane separator. The quencher reduces the gas temperature from 300 to $66^{\circ} \mathrm{C}$, and provides some scrubbing action to remove $90 \%$ of particulates and semivolatile radionuclides. The tandem nozzle scrubber's primary functions are to remove an additional $90 \%$ of particles $0.5 \mathrm{\mu m}$ dia and larger, condense remaining semivolatile components, and provide additional cooling of the of $f$ gas. The vane separator that follows each tandem nozzle scrubber removes all droplets $12 \mu \mathrm{m}$ and larger. Under the conditions given in the mass and energy balance (Table 2), the exit temperature from the scrubber system is $60^{\circ} \mathrm{C}$. 
The scrub solution injected into the quenchers and tandem nozzle scrubbers is cooled through two single-pass heat exchangers before being returned to the process scrub tanks. Each heat exchanger measures $2.5 \mathrm{~m}$ long $\times 20 \mathrm{~cm}$ dia. Each can remove $120 \mathrm{~kW}$ from the scrub solution, which flows at $178 \mathrm{~L} / \mathrm{min}$ from $62^{\circ} \mathrm{C}$ as it exits the scrubber system to $52^{\circ} \mathrm{C}$. Each heat exchanger transfers the heat to a glycol solution flowing at $760 \mathrm{~L} / \mathrm{min}$.

Two independent scrub pumps recirculate the scrub solution from the process tanks to the wet scrubbers. Each pump's suction is located within $15 \mathrm{~cm}$ of the bottom of the lowest portion of its respective tank. Each pump can deliver $510 \mathrm{~L} /$ min with a maximum deliverable pressure of $14.5 \mathrm{KPA}$ (100 psig). In addition, the scrub pumps can flush out the gas cooler and offgas piping that are not wetted by the wet scrubbers.

Following the scrubber systems, the off gas is recombined and cooled further from 60 to $52^{\circ} \mathrm{C}$ in a single-pass condenser. The condenser and mist eliminator provide additional decontamination of the off gas (90 to $99 \%$ removal) by condensation and removal of water droplets. The condenser, which measures $3.26 \mathrm{~m}$ long $\times 61 \mathrm{~cm}$ dia, transfers $320 \mathrm{~kW}$ from the off gas into glycol flowing at $1500 \mathrm{~L} / \mathrm{min}$. The mist eliminator, a vane separator measuring $1.2 \mathrm{~m}$ long from flange to flange, removes droplets $12 \mu m$ and larger (Euroform 1984). Both the condenser and mist eliminator are rated at 104 standard $\mathrm{m}^{3} / \mathrm{min}$ at the out let.

After the condenser/mist eliminator, the gases flow to the heater and HEPA filters. To prevent moisture condensation in the HEPA filters, the off gas is reheated by $25^{\circ} \mathrm{C}$ to $77^{\circ} \mathrm{C}$ in the heater. The heater, which measures $2.6 \mathrm{~m} \mathrm{long}$ $\times 0.70 \mathrm{~m} \mathrm{dia}$, is capable of raising the off-gas temperature by a maximum of $50^{\circ} \mathrm{C}$ at 104 standard $\mathrm{m}^{3} / \mathrm{min}$. Final decontamination of off-gas particulates is achieved in the two-stage HEPA filter assemblies. The first stage is composed of two parallel housings, each capable of holding four $61 \mathrm{~cm} \times 61 \mathrm{~cm} \times 30 \mathrm{~cm}$ deep filters. If a filter's differential pressure becomes too high, the off gas will be autonatically diverted to the parallel housing. Fach filter is rated at 28 standard $\mathrm{m}^{3} / \mathrm{min}$ at $2.08 \mathrm{~cm}\left(0.82 \mathrm{in.)}\right.$ water ${ }^{8}$ for a total rating of 113 standard $\mathrm{m}^{3} / \mathrm{min}$ per filter housing. 
The gaseous effluents are drawn through the off-gas system components by an induced draft system. The driving force is provided by a $149 \mathrm{~kW}$ (200-hp) blower capable of achieving 104 standard $\mathrm{m}^{3} / \mathrm{min}$ at $90^{\circ} \mathrm{C}$ and $-229 \mathrm{~cm}(-90$ in.) of water. A backup blower rated at one-quarter the capacity is also provided in the event of failure of the primary blower. The backup blower is not intended to provide excess combustion air, but rather to maintain a negative pressure on the of $f$-gas hood to prevent direct release of effluents until the process can be safely shut down. The backup blower is automatically activated by the process control system when the beader vacuum is reduced below a preset limit. After the blower system, the off gases are exhausted to the stack, which is monitored continuously for radionuclides, $\mathrm{NO}_{x}$ and $\mathrm{SO}_{2}$. The stack is removable and extends high enough $(3 \mathrm{~m})$ to prevent interference with the offgas and control trailer's heating, ventilating and air conditioning (HVAC) systems.

\section{GTycol Cooling System}

Glycol cooling solution is pumped between the support trailer and off-gas trailer to remove the heat from the gaseous effluents. The glycol is recirculated between trailers through flexible jumpers by two pumps in two independent loops. The glycol recirculating through the heat exchangers and condensers is kept separate from the glycol loop for the gas cooler. Both loops, however, are assembled in one glycol cooling assembly which is located on the support trailer. The assembly consists of two fan-cooled radiator systems, each dedicated to its respective glycol loop. The entire assembly, which fits on the front $5 \mathrm{~m}$ of the support trailer, will remove $1600 \mathrm{~kW}$ at an ambient temperature of $38^{\circ} \mathrm{C}$.

\section{Process Control Station}

The process control station consists of a distributed microprocessor monitoring and control system, and a control console for the power supply. It monitors and controls important process parameters. In addition, it automatically activates backup equipment or reroutes off-gas flow in the event that certain equipment fails. 
The distributed microprocessor controt system consists of three process control units (PCUS) and two operators interface units (0IUs). The PCUs are connected to critical and informational sensors located throughout the process. These include sensor readings from pressure elements, thermocouples, gas monitors, and flowmeters. In addition to monitoring key parameters, the control system controls the pressure drop across the scrubber systems by a pneumatic flow control valve at the blower inlet. It also controls the blower inlet vacuum with a separate pneumatic valve that governs the magnitude of recycle through the main blower. The control system can automatically activate the standby scrubber system if hood vacuum or oxygen concentration were to be reduced. This action subsequently increases the flow capacity of the process to 104 standard $\mathrm{m}^{3} / \mathrm{min}$. The control system also provides automatic batch logic sequencing of specific operations in the event of equipment failure. For example, the control system will automatically restart the off-gas system in a preprogrammed sequence in the event of power failure. And it will automatically activate the parallel HEPA filter assembly if pressure drop exceeds predetermined levels. Also, it will automatically shut down power to the electrodes and start the backup blower upon primary blower failure.

Although the control system is connected to sensors and to an automatic shutdown circuit on the electrode power supply system, it does not directly control the power supply. A separate control console fulfills that function. The power supply controller provides the necessary saturation current to the saturable reactors that govern the power to the electrodes. This control module maximizes efficiency of the electrode power system and provides a quick reduction in power in the event of off-standard conditions. Off-Gas Support Equipment

Various support and backup equipment are necessary to ensure the safe operation of the off-gas system. This equipment provides electrical, water, and air services to the of $f$ gas equipment. The support equipment includes a 750-kVA transformer; a motor control center; a 112-kVA transformer; a 750-kVA diesel generator; an air compressor; and a process water supply tank, pump, and agitator. 
Other than electrical power, the in situ vitrification process is entirely self contained. No outside water, sewer, or air services are required. Supply and waste waters are transported by tank truck on an as-needed or scheduled basis. The process is equipped with its own air compressor for actuation of the pneumatic valves, and its own water supply tank for scrub solution makeup.

Power to the off-gas process equipment is provided through the 750-kva transformer and distributed by the motor control center. The 750-kVA transformer, located on the support trailer, provides $480 \mathrm{~V}$ power to the motor control center from a $13.8-k V$ supply. If power is interrupted to the transformer, a transfer switch in the motor control center will automatically activate a standby 600-kw, 750-kVA diesel generator that is equipped with its own battery powered cranking system. This generator will provide emergency power to all off-gas system components including the pumps and fans of the glycol cooling assembly, the two scrub pumps, the heater, the blower system, the air compressor, and monitoring and control instrumentation. The motor control center, located in the control trailer, provides power to this equipment as well as to the power supply control console and the supply pump and agitator for process water. The 112-kVA transformer, which provides $240 \mathrm{~V}$ and $120 \mathrm{~V}$ power from $480 \mathrm{~V}$, is also located in the control trailer. The 120-V power is also tied into the emergency backup power generator for emergency lighting. 
. 
PROCESS CAPABILITIES

Recause no two waste sites requiring remedial action have the same geometry or hazardous waste inclusions, the ISV process must be flexible enough to adapt to a wide range of buried waste parameters. The depth of the waste may vary from contaminated soil near the surface to contaminant plumes that extend far underground. Waste sites may contain metal distribution pipes or 55-gal drums that must not interfere with the process's ability to distribute electrical power into the molten soil. Also, pyrolized gases from combustible organics must be contained, burned, and treated before release to the atmosphere. The ISV off-gas system must be able to renove a variety of contaminants from the gaseous effluents to within acceptable environmental criteria. For these reasons, restrictive design criteria were established for the large-scale ISV process.

GEOMETRIC FLEXIBILITY

The electrode power supply provides the means to vitrify to a depth of 10 to $13 \mathrm{~m}$ with a square array of electrodes, each separated by $3.5 \mathrm{~m}$. If the surface is not contaminated, the soil may be excavated to bring the contaminated soil to within $13 \mathrm{~m}$ of the surface. A maximum electrode separation of $5.5 \mathrm{~m}$ can be obtained at a reduced vitrification depth. The attainable vitrification depths are established from the results of a mathematical model that represents large-scale process performance based on results from pilotscale and engineering-scale tests (0ma 1983). The model can represent two basic process conditions. Depending on various processing parameters, the surface of the vitrified zone can be molten, represented by a high heat loss assumption in the model, or it can be covered by a cold cap, represented by a low heat loss assumption. Figure 7 shows the attainable vitrification depths as functions of electrode separations for both heat loss assumptions. The $13 \mathrm{~m}$ depth represents a theoretical limitation at 3.5-m electrode separation using the high heat-loss assumption. The practical limit is $10 \mathrm{~m}$. However, much greater depths are attainable under low heat loss conditions. 


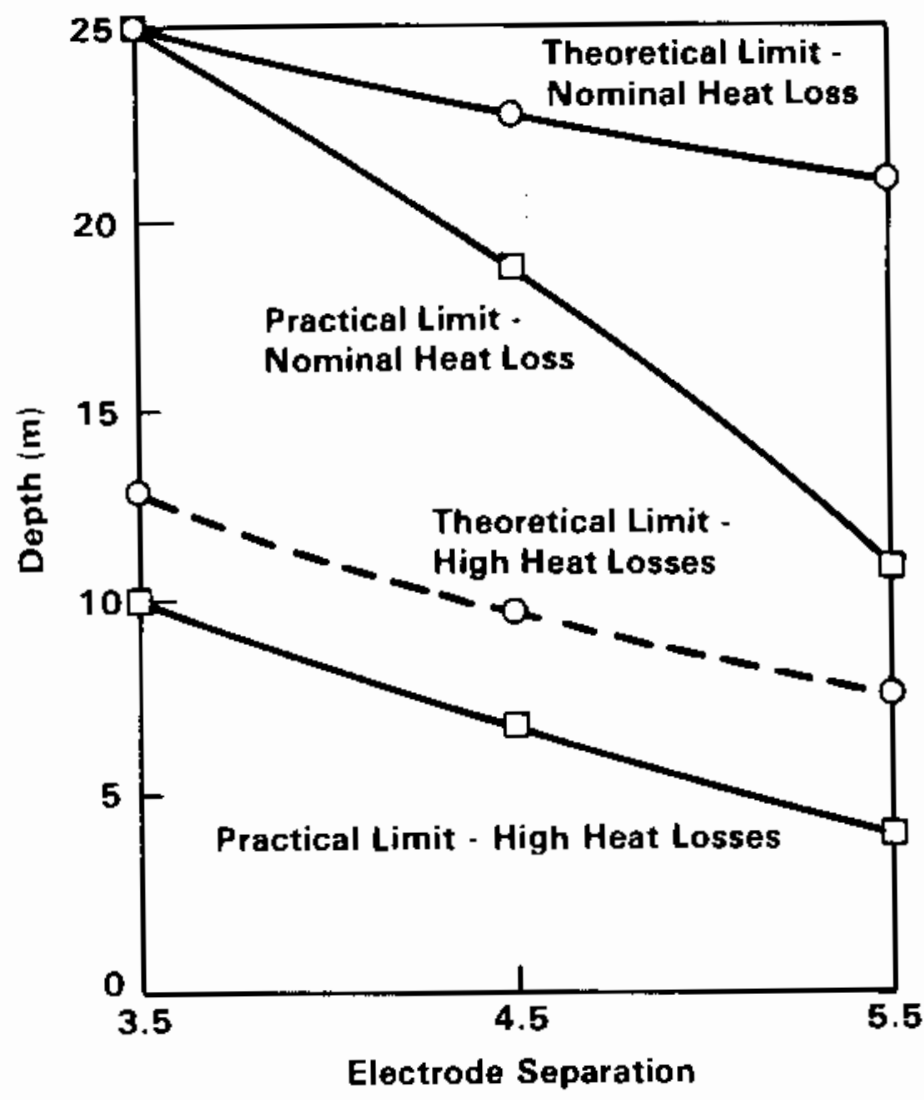

FIGURE 7. Attainable Vitrification Depths

INCLUSION OF METALS

The electrical system is capable of processing a certain geometric configuration of metals. An excessive amount of metals in the contaminated soil can potentially create an electrical "short" between electrode pairs, thereby limiting the amount of power distributed to the melt. Oma (1983) has shown through a mathematical analysis that metal components such as distribution pipes and metal drums will not adversely affect process performance, provided they do not exceed certain limitations. Experimental data demonstrate that at least $70 \%$ of the linear separation between electrodes and 5 wt $\%$ of the total mass of contaminated soil can be occupied by metal (Ona 1983). However, maximum limits have not yet been established. 


\section{SITE CONTOUR}

The hood covering the area being vitrified is designed to accommodate variations in site contour and level. With leveling devices, the hood can accommodate a maximum variation in contour of $\$ 15 \mathrm{~cm}$ at a maximum slope of $5^{\circ}$. Variations in contour greater than these restrictions can be accommodated by leveling the site prior to vitrification.

\section{OFF-GAS CONTAINMENT}

During ISV of contaminated soil or buried wastes, certain inclusions in the soil, such as combustibles, sealed containers, and void volumes, can generate rapid releases of of gases. Techniques such as ground-penetrating radar (Koerner and Lord 1984) exist for identifying such inclusions, and pretreatment techniques would be employed to mitigate the rate of of gas released during processing. Nevertheless, the hood and off-gas system are designed to contain and treat such off-gas releases with a sufficient safety factor.

\section{Maximum Conditions}

The nominal capacity of the off-gas system is 50 standard $\mathrm{m}^{3} / \mathrm{min}$. This is based on measured in-leakage around the hood of the pilot-scale system. The hood perimeter, where most in-leakage is expected to occur, is four times that of the pilot-scale unit whose off-gas capacity is 12.5 standard $\mathrm{m}^{3} / \mathrm{min}^{n}$. Thus the base capacity of the large-scale system is set at 50 standard $m^{3} / m_{i n}$. However, when combustibles are present, the combined flow of pyrolyzed gases and combustion air is 52 standard $\mathrm{m}^{3} / \mathrm{min}$. Maximum capacity of the off-gas system, based on maximum combustion rates and a design factor of two, is therefore 104 standard $\mathrm{m}^{3} /$ min at a maximum off-gas temperature of $750^{\circ} \mathrm{C}$.

The off-gas system is designed to accommodate the maximum conditions of combustion, sealed containers, and void volumes that are anticipated at a contaminated soil site or burial ground. It is designed for solid combustible concentrations of not more than $3,200 \mathrm{~kg} / \mathrm{m}$ of depth per setting, with a minimum soil or other noncombustible content of $30 \mathrm{vol} \%$. The presence of soil is necessary to slow the advance of molten soil through the combustible region, 
thereby controlling the rate of pyrolysis of the combustibles. The off-gas system can also accommodate organic liquid combustible components not greater than $4800 \mathrm{~kg} / \mathrm{m} / \mathrm{setting}$ or $7 \mathrm{wt} \%$ assuming the soil is consolidated with no sealed containers (e.g., drums or buckets). Single solid combustible volumes may not exceed $0.9 \mathrm{~m}^{3}$ at a density of $240 \mathrm{~kg}$ combustibles $/ \mathrm{m}^{3}$. Combustible liquid contents inside sealed containers may not exceed $50 \mathrm{~kg}$ unless the sealed containers are ruptured prior to vitrification or until additional data are collected on how sealed containers that contain combustible liquids behave during vitrification.

Because of resource limitations, the existing off-gas hood is presentiy designed under less stringent conditions. It will accommodate combustion that occurs from organic liquids if their concentration in the consolidated soil not greater than $2300 \mathrm{~kg} / \mathrm{m} / \mathrm{setting}$ or $3 \mathrm{wt} \%$. When the demand arises, a high temperature hood could be designed and fabricated to accommodate the heat load that arises from more severe combustible conditions.

Bases for Maximum Conditions

The solid combustible criterion of $3200 \mathrm{~kg} / \mathrm{m}$ for the off-gas system is limited by the system's capacity and the heat-removal capabilities of the hood and off-gas system. The criterion is based on worst-case expectations for a burial trench where solid wastes are distributed and covered with soil. If less than 30 vol\% soil is distributed with the solid wastes, molten soil will advance through the combustibles and pyrolyze them in excess of design capabilities. In this case, the single combustible volume limit of $0.9 \mathrm{~m}^{3}$ must be met. The liquid combustible limit for the off-gas system is based on gas flow and heat generation limits equivalent to the solid combustible concentration of $3200 \mathrm{~kg} / \mathrm{m}$, while that for the of $\mathrm{f}-\mathrm{gas}$ hood is based on extreme estimates of organic liquid contents at a liquid drain site at the Hanford Site, Washington (Zimmer 1973). The 50-kg liquid combustible limit for sealed containers is based on pilot-scale empirical data.

The maximum effluent rate from solid combustibles is based on the following equation:

$$
V^{\prime}=v \cdot(1 \cdot w \cdot p B) \cdot x \cdot 0.0038 / M W
$$


where $\quad V^{\prime}=$ pyrolyzed gas generation rate (standard $m^{3} / \mathrm{min}^{\mathrm{n}}$ )

$$
\begin{aligned}
v= & \text { melt velocity downward }(\mathrm{cm} / \mathrm{h}) \\
\left(1 * w^{*} \mathrm{pB}\right)= & \text { concentration of combustibles per meter depth } \\
& (\mathrm{kg} / \mathrm{m}) \\
\mathrm{X}= & \text { mass pyrolyzed gas/mass solid (assume } 0.85) \\
M W= & \text { average molecular weight of pyrolyzed gases. }
\end{aligned}
$$

Based on the mathematical model that predicts large-scale processing behavior, the downward melting velocity in soil is $7 \mathrm{~cm} / \mathrm{h}$. Solid combustibles with only 30 vol\% soil will logically increase the melting velocity by a factor of $1 /(0.3)$. Assuming the concentration of compacted solid combustibles is $3200 \mathrm{~kg} / \mathrm{m}$, the rate of pyrolyzed gas generation is therefore $16 \mathrm{~m}^{3} / \mathrm{min}$. Assuming the solid wastes are chemically similar to wood (i.e., 47 wt\% carbon, 6 wt \% hydrogen, and 47 wt \% oxygen), $5 \%$ of the gas generated from pyrolyzed solid wastes would be noncombustible $\mathrm{CO}_{2}$ (Mudge et al. 1980). This leaves $15.2 \mathrm{~m}^{3} / \mathrm{min}$ of combustible gas. The amount of oxygen required for combustion can be calculated from the remaining pyrolyzed gases $(42$ molar\% Co and 53 molar\% $\mathrm{H}_{2}$ ). Using a $20 \%$ excess combustion air rate, and accounting for the combustion products and the noncombustible portion, the total effluent rate is $52 \mathrm{~m}^{3} / \mathrm{min}$. Because the off-gas system capacity is $104 \mathrm{~m}^{3} / \mathrm{min}$, this allows a safety factor of two.

The heat release from combustion is determined from standard heats of combustion of the pyrolyzed gases. The heat generated from combustion under the maximum conditions is $3000 \mathrm{~kW}$. This heat and the heat transferred to the gases that pass through the molten soil zone are removed by natural radiative and convective heat transfer from the hood surface and off-gas 1 ine, and by forced convection through the heat exchangers and condenser in the off-gas system. Maximum combustible conditions result in a hood-skin temperature of $930^{\circ} \mathrm{C}$ and an entrance temperature into the off-gas system of $750^{\circ} \mathrm{C}$. As indicated earlier, the existing hood is not designed under maximum combustible conditions. It is instead based on maximuln combustible conditions expected at a contaminated soil site at Hanford as opposed to a buried waste site. The existing hood can withstand maximum continuous temperatures of $550^{\circ} \mathrm{C}$ and heatup rates of $50^{\circ} \mathrm{C} / \mathrm{min}$ without compromising its ability to maintain the design 
vacuum. The hood can accommodate combustible conditions of $1,400 \mathrm{~kW}$ at the surface of the vitrified zone, distributed evenly among the four electrodes.

The maximum single combustible volume of $0.9 \mathrm{~m}^{3}$ in the soil is based on release rate observations from pilot-scale tests. When vitrifying combustible solid volumes, molten soil flows into and contacts the combustibles, rapidly pyrolyzing the contents. This creates a surge in of $f$-gas effluent rates, which, by recorded observations, occur logarithmically over a 30-min period. A logarathmic release curve such as the one shown in Figure 8 can be fitted to the following equation:

$$
t=a \cdot \ln \left(V^{\prime} / V_{0}{ }^{\prime}\right)
$$

which when integrated gives:

$$
V=v_{0}{ }^{\prime} \int_{t=0}^{30 \min } e^{(t / a)} d t
$$

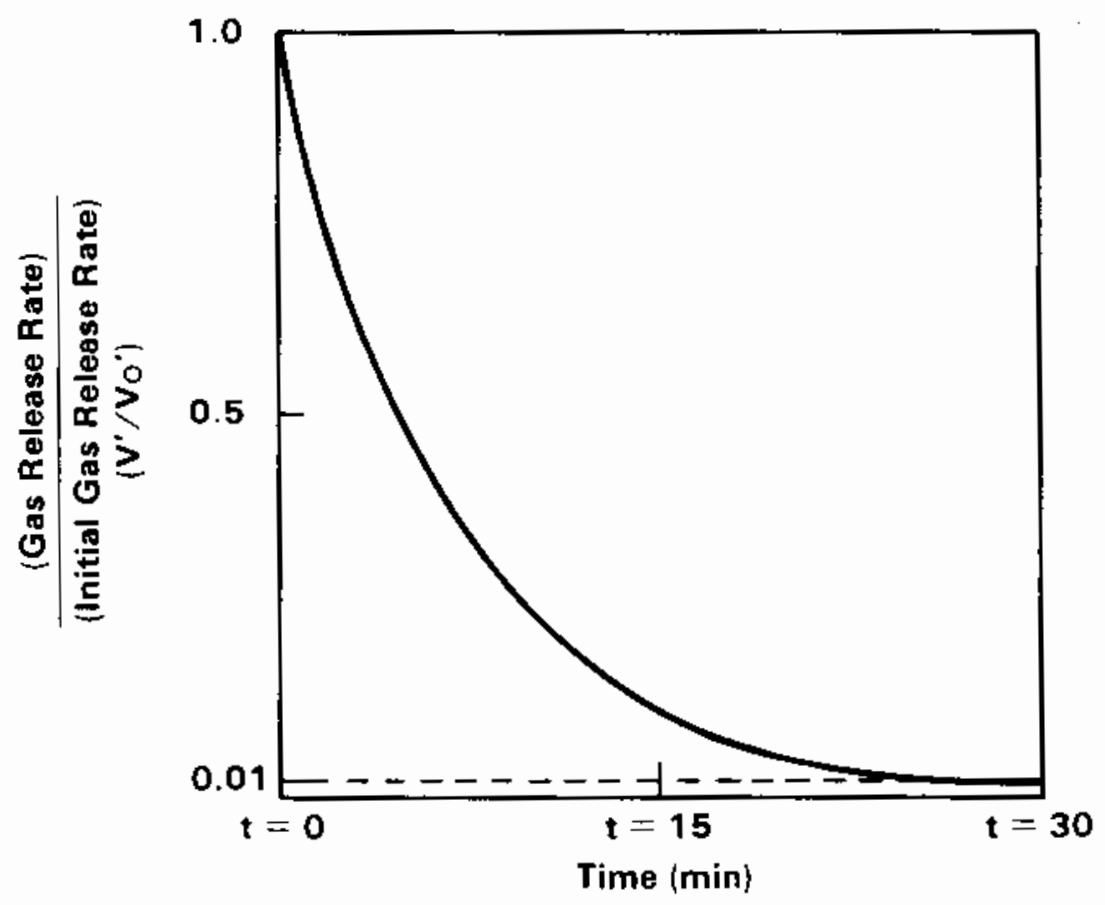

FIGURE 8. Gaseous Release Rate for Single Combustible Volumes 
where $V=$ volume of gas released over the 30-min time period

(the integrated area of the curve $-m^{3}$ )

$V^{\prime}=$ rate of gas released $\left(m^{3} / \mathrm{min}^{\prime}\right)$

$V_{0}{ }^{\prime}=$ release rate at time zero $\left(15.2 \mathrm{~m}^{3} / \mathrm{min}\right.$ from the maximum allowable combustible condition with a safety factor of two)

$t=\operatorname{time}(\min )$

$a=$ constant $(-6.5 \mathrm{~min})$.

from this equation, the maximum volume of gas generation is calculated to be 98 standard $\mathrm{m}^{3}$. This correlates to a solid combustible volume of $0.48 \mathrm{~m}^{3}$. Eliminating the design factor of two increases the design capacity of the system to approximately $0.9 \mathrm{~m}^{3}$ while maintaining $20 \%$ excess combustion air. For a sudden release of pyrolyzed gases, only containment is required. However, the calculation allows for $20 \%$ excess combustion air. Merely containing the release provides a sufficient safety factor (i.e., 6.5 for containment of pyrolyzed gases).

Single-void volumes, such as a burial box or empty barrel less than $4.3 \mathrm{~m}^{3}$, can also be accommodated by the hood and off-gas system. This volume is based on the pilot- and engineering-scale observations that noncombustible gases inside the void are released uniformly over a 5-sec period. The gases associated with the void volume in the contaminated soil are displaced by molten glass over this time period. No combustion takes place, so the maximum allowable release rate is $52 \mathrm{~m}^{3} / \mathrm{min}$ to allow for sufficient safety factor. A simple calculation of a linear release over 5 seconds reveals that a maximum void volume of $4.3 \mathrm{~m}^{3}$ can be accommodated in the soil without jeopardizing the ability of the process to contain and treat gaseous effluents and to maintain a design factor of two.

OFF-GAS TREATMENT CAPABILITIES

The gases emanating from the molten soil carry a small percentage of radionuclides (transuranics and fission products) or heavy metal particulates. The gases must therefore be decontaminated before being released to the atmosphere. The off-gas system accomplishes this by providing a minimum decontamination factor (DF) of $10^{5}$ for transuranics and particulates and $10^{4}$ for semi- 
volatiles, such as cesium and cadmium. The decontamination factor is a measure of the removal efficiency of a component or system and is defined as

$$
D F=\frac{[A]_{j}}{[A]_{e}}
$$

where $[A]_{j}=$ concentration of element $A$ fed to the component, and

$[A]_{e}=$ concentration of element $A$ exiting the component.

The HEPA filters have a normal DF rating of $10^{3}$ each (Flanders 1984 ). However, to achieve an additional safety factor in design, for the large-scale ISV process they are assumed to have a combined DF of only 10 . The off-gas system DFs are based on particle sizes of $0.3 \mu \mathrm{m}$ and greater. Emperical data from pilot-scale tests show no significant concentrations below this size (Oma and Timmerman 1984).

The Environmental Protection Manual (Rockwell Hanford Operations 1985) establishes effluent release requirements for radioactive operation at the Hanford Site, for which the process was originally designed. Annual average concentrations may not exceed the limits of 10 CFR 20 Table II (U.S. CFR 1984) at the point of release (i.e., the stack). Table 3 compares the Table II limits with the annual average concentrations, which were calculated from the design off-gas system DFs and the $99.98 \%$ transuranic soil retention figure measured from past tests (Timmerman and Oma 1984). Concentrations at the stack are well below Table II limits. We suspect this type of removal efficiency will far exceed the requirements for hazardous waste sites.

TABLE 3. Comparison of Stack Effluent Concentrations with Environmental Requirements

\begin{tabular}{lll} 
Annual Average Concentration & & $\begin{array}{l}\text { Table II Limits } \\
\text { from 10 CFR 20 }\end{array}$ \\
\hline $2399_{\mathrm{Pu}}=2.5 \times 10^{-13} \mu \mathrm{Ci} / \mathrm{mL}$ & & $1 \times 10^{-12} \mu \mathrm{Ci} / \mathrm{mL}$ \\
$240_{\mathrm{Pu}}=6.3 \times 10^{-14} \mu \mathrm{Ci} / \mathrm{mL}$ & $1 \times 10^{-12} \mu \mathrm{Ci} / \mathrm{mL}$ \\
$241_{\mathrm{Am}}=1.0 \times 10^{-12} \mu \mathrm{Ci} / \mathrm{mL}$ & $4 \times 10^{-12} \mu \mathrm{Ci} / \mathrm{mL}$
\end{tabular}


EQUIPMENT DESIGN LIFE

The large-scale ISV unit is designed for a 10-yr lifetime. Except for easily replaceable or maintainable instrumentation, the power equipment will meet the 10-yr criterion. The hood is designed for a 10-yr life under moderate conditions (i.e., $350^{\circ} \mathrm{C}$ maximum continuous temperature for $200 \mathrm{~h}$ followed by a downtime of $400 \mathrm{~h}$ cooling to ambient conditions). Otherwise, if extreme conditions exist, the hood is considered to be expendable after one year of use. Extreme conditions exist when a maximum of $550^{\circ} \mathrm{C}$ is experienced at the center of the hood cycling to $350^{\circ} \mathrm{C}$ at $50^{\circ} \mathrm{C} / \mathrm{min}$ every hour for $200 \mathrm{~h}$ followed by a downtime of $400 \mathrm{~h}$ cooling to ambient conditions. Extreme conditions also exist during operation when internal nitrate, sulfate, and chloride concentrations reach a maximum of $2.5 \%, 0.5 \%$, and $0.5 \%$ respectively. The off-gas system and monitoring equipment are also designed for a 10-yr life. Any off-gas equipment with less than a 10-yr expected lifetime (i.e., pumps, heater elements, and the gas cooler) can be replaced and/or maintained.

The design life of the off-gas system is based on published corrosion rates. All pipelines less than 6 in. nominal are constructed of Schedule $40 \mathrm{~S}$ 304-L stainless steel. Six-in. and greater diameter pipelines are Schedule $10 \mathrm{~S}$ 304-L. The schedule specification ensures that the minimum wall thickness will be $0.34 \mathrm{~cm}$ for any pipe in the process. Lewis, Driggers and Malki (1981) have shown emperically that corrosion rates can he held to less than $0.025 \mathrm{~cm} / \mathrm{y}$ at $\mathrm{pH}=8$ for the $0.5 \%$ chloride concentrations to which the process was designed. This corrosion rate will be acceptable for a 10-yr life. Also, great care was taken in fabrication to eliminate internal crevices to reduce cracking caused by stress corrosion. 
4

$-$ 


\section{WASTE FORM QUALITY}

The large-scale ISV process is capable of producing a high-quality waste form that incorporates hazardous nonvolatile elements such as heavy metals for geologic periods. The product's leaching characteristics are similar to granite and superior to marble and common bottle glass (Oma 1983). The ISV product's analogue, obsidian, exhibits extremely small hydration rates, such that the resulting waste form's effective lifetime can be expected to exceed one million years. 
-

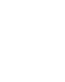

$-$

. 


\section{CONCLUSIONS}

The large-scale ISV process is self-contained in a transportable system for stabilizing contaminated soil in place. The process equipment is mounted in three trailers for easy transport among various waste sites. Other than 13.8-kV electrical power, the large-scale system requires no facility services, such as compressed air or cooling water.

The ISV process is designed and fabricated using commercially available equipment. This results in reduced capital costs and process equipment replacement costs. The total system is designed to be operated under normal conditions by two operators per shift, to control operational costs. Its flexible design features allow ISV to be considered for remedial action for contaminated soil sites. 
.

. 


\section{REFERENCFS}

Euroform. 1984. (Design Brochure) "Mist Eliminator," TS 5 Series, The Munters Corporation, Fort Myers, Florida, 1984.

Flanders Filters, Inc. 1984. "Nuclear Grade HEPA Filters," Bulletin No. 812A, Washington, North Carolina.

Hazardous Materials Control Research Institute. 1984. FOCUS, Silver Spring, Maryland, October issue, pg. 1.

Koerner, R. M. and A. E. Lord Jr. 1984. "NDT Location of Containers Buried in Saline Contaminated Soils," in Proc. of the 5th National Conference on Management of Uncontrolled Hazardous Waste Sites, p. 158. Hazardous Materials Control Research Institute, Silver Spring, Maryland.

Lazar, I. 1977. "Making the Choice Among Dry, Liquid, and Gas Transformers," Specifying Engineering, 37.

Lewis, E. C., G. W. Driggers, and K. W. Malki. 1981. Laboratory Evaluation of Several Alloys in High-Chloride FGD Environment, in Solving Corrosion Prohlems in Air Pollution Control Equipment, National Association of Corrosion Engineers, Houston, Texas.

Mudge, L. K., D. G. Ham, S. L. Weber, and D. H. Mitche11. 1980. Oxygen/Steam Gasification of Wood, PNL-3353, Pacific Northwest Laboratory, Richland, Washington.

Oma, K. H., et al. 1983. In Situ Vitrification of Transuranic Wastes: Systems Evaluation and Applications Assessment, PNL-4800, Pacific Northwest Laboratory, Richland, washington.

Oma, K. H. and C. L. Timmerman. 1984. "Off-gas Treatment and Characterization for a Radioactive In Situ Vitrification Test, in Proc. 18th Nuclear Airborne Waste Management and Air Cleaning Conference, TechnicaT Information Center, oak Ridge, Tennessee.

Rockwell Hanford Operations Energy Systems Group. 1985. Environmental Protection Manua 1, RH0-MA-139, Rockwel1 Hanford Operations, Richland, Washington.

Timmerman, C. L. and K. H. Oma. 1984. An In Situ Vitrification Pilot-Scale Radioactive Test, PNL-5240, Pacific Northwest Laboratory, Richland, Washington.

Timmerman, C. L., R. A. Brouns, J. L. Buelt, and K. H. Oma. 1983. In Situ Vitrification: Pilot-Scale Development," Nuclear and Chemical Waste Management, $4: 267$. 
U.S. Code of Federal Regulations. 1984. Title 10, Part 20, Table II, Government Printing office, Washington, D.C.

U.S. Code of Federal Regulations. 1984. Title 23, Section 127, Government Printing office, Washington, D.C.

World Information Systems, Hazardous Materials Intelligence Report, "Proposed National Priorities List of 418 Sites, "Cambridge, Massachusetts, 1982, pp. $1-16$.

Zimmer, W. H. 1973. Interim Report: Sampling Techniques and Analysis of 219-2-9 Covered Trench, ARH-2752, Rockwell Hanford Operations, Richland, Washington. 
No. of

Copies

OFFSITE

30

\author{
DOE Technical Information \\ Center
}

J. $W$. Bennett, RW-20

Geologic Repository Division

DOE Office of Civilian

Radioactive Waste Management

Forrestal Building

C. R. Cooley, RW-4

Geologic Repository Division

DOE Office of Civilian

Radioactive Waste Management

Forrestal Building

M. W. Frei

Geologic Repository Division

DOE Office of Civilian

Radioactive Waste Management

Forrestal Building

B. C. Rusche, RW-1

Geologic Repository Division

DOE Office of Civilian

Radioactive Waste Management

Forrestal Building

R. Stein, RW-23

Geologic Repository Division

DOE Office of Civilian

Radioactive Waste Management

Forrestal Building

D. B. LeClaire, DP-12

DOE Office of Defense Waste \& GTN Byproducts Management

Washington, OC 20545

R. D. Walton, Jr., DP -123

DOE Office of Defense Waste \& GTN

Byproducts Management

Washington, DC 20545
No. of

Copies
J. Jicha DP-123

DOE Office of Defense Waste \& Byproducts Managenent GTN

Washington, DC 20545

J. E. Baublitz, NE-24

DOE Office of Terminal Waste

Disposal \& Remedial Action GTN

Washington, DC 20545

J. A. Coleman, NE-25

DOE Office of Terminal Waste GTN

Disposal \& Remedial Action

Washington, DC 20545

D. J. McGoff, NE-23

DOE Office of Terminal Waste GTN

Disposal \& Remedial Action

Washington, DC 20545

J. A. Turi, NE- 25

DOE Office of Terminal Waste GTN

Disposal \& Remedial Action

Washington, DC 20545

W. R. Voigt, NE-20

DOE Office of Terminal Waste GTN

Disposal \& Remedial Action

Washington, DC 20545

H. F. Walter, NE-25

DOE Office of Terminal Waste GTN

Disposal \& Remedial Action

Washington, DC 20545 
No. of

Copies

J. B. Zorn, NE-25

DOE Office of Terminal Waste Disposal \& Remedial Action

GTN

Washington, DC 20545

M. J. Bell

Division of Nuclear Materials Safety \& Safeguards

Mail Station 881-SS

Nuclear Regulatory Commission

Washington, DC 20555

\section{A. T. Clark \\ Division of Fuel Material Safety}

Nuclear Regulatory Commission

Washington, DC 20555

W. J. Dircks

Office of the Executive Director for Operations

Mail Station 6209

Nuclear Regulatory Commission Washington, DC 20555

D. Egan

Environmental Protection Agency office of Radiation Programs

401 M Street, S.W.

Washington, DC 20460

G. L. Sjoblom

Environmental Protection Agency

Office of Radiation Programs

401 M Street, S.W.

Washington, DC 20460

M. McFadden

DOE Albuquerque Operations office

P.0. Box 5400

Albuquerque, NM 87185
No. of

Copies

J. MeGough

DOE Albuquerque Operations Office

P.0. Box 5400

Albuquerque, NM 87185

W. H. Hannum

DOE West Valley Operations office

P.0. Box 191

West Valley, NY 14171

J. D. Hamric

DOE Idaho Operations office

550 Second Street

Idaho Falls, ID 83401

J. B. Whitsett

DOE Idaho Operations office

550 Second Street

Idaho Falls, ID 83401

L. Lanni

DOE San Francisco Operations

1333 Broadway

San Francisco, CA 94612

W. E. Pasko

DOE Oak Ridge Operations Office

P.0. Box E

Oak Ridge, TN 37830

S. A. Mann

DOE Chicago Operations Dffice 9800 South Cass Avenue

Argonne, IL 60439

J. 0. Neff

DOE National Waste Program office

$505 \mathrm{King}$ Avenue

Columbus, $\mathrm{OH} 43201$

G. K. Dertel

DOE Savannah River Operations Office

P.0. Box A

Aiken, SC 29801 
No. of

Copies

0. L. Vieth

DOE Nevada Dperations Office

P.0. Box 14100

Las Vegas, NV 89114

C. S. Abrams/J. H. Kittel

Argonne National Laboratory

9700 South Cass Avenue

Argonne, IL 60439

M. J. Steindler/L. E. Trevorrow

Argonne National Laboratory

9700 South Cass Avenue

Argonne, IL 60439

W. J. Madia

Battelle Menorial Institute

office of Crystalline

Repository Development

9800 South Cass Avenue

Argonne, IL 60439

W. A. Carbeiner/S. H. Basham

Battelle Memorial Institute

Project Management Division

505 King Avenue

Columbus, $\mathrm{OH} 43201$

J. F. Kircher

Battelle Menorial Institute

Project Management Division

505 King Avenue

Columbus, $\mathrm{OH} \quad 43201$

R. Rawles

Battelle Memorial Institute

Project Management Division

505 King Avenue

Columbus, OH 43201

F. Holzer

Lawrence Liverinore National

Laboratory

University of California

P.0. Box 808

Livermore, CA 94550
No. of

Copies

D. T. Oakley, MS 671

Los Alamos Scientific

Laboratory

P.0. Box 1663

Los Alamos, NM 87544

T. H. Row

Oak Ridge National Laboratory

P.0. Box $X$

nak Ridge, TN 37830

J. 0. Blomeke

Oak Ridge National Laboratory

P.0. Box $Y$

Oak Ridge, TN 37830

W. D. Burch

Oak Ridge National Laboratory

P.0. Box $Y$

Oak Ridge, TN 37830

L. A. Dole

Oak Ridge National Laboratory

P.0. Box $Y$

Dak Ridge, TN 37830

D. R. Anderson

Sandia Laboratories

P.0. Box 5800

Albuquerque, NM 87185

J. F. Ney

Sandia Laboratories

P.0. Box 5800

Albuquerque, NM 87185

R. W. Lyncb

Sandia Laboratories

P.0. Box 5800

Albuquerque, NM 87185 
No. of Copies

W. Weart

Sandia Laboratories

P.0. Box 5800

Albuquerque, NM 87185

Technical Library

Sandia Laboratories

P.0. Box 5800

Albuquerque, NM 87185

B. R. Wheeler

Westinghouse Idaho Nuclear Co., Inc.

P.0. Box 4000

Idaho Falls, ID 83401

M. D. Boersma

E. I. du Pont de Nemours Company

Savannah River Laboratory

Aiken, SC 29801

J. L. Crandall

E. I. du Pont de Nemours Company

Savannah River Laboratory

Aiken, SC 29801

E. J. Hennelly

E. I. du Pont de Nemours Company

Savannah River Laboratory

Aiken, SC 29801

L. L. Kilpatrick/L. M. Lee

E. I. du Pont de Nemours Company

Savannah River Laboratory

Aiken, SC 29801

S. Mirshak

E. 1. du Pont de Nemours Company

Savannah River Laboratory

Aiken, SC 29801
No. of

Copies

\author{
R. M. Wallace \\ E. I. du Pont de Nemours \\ Company \\ Savannah River Laboratory \\ Aiken, SC 29801 \\ E. A. Jennrich \\ EG\&G Idaho \\ P.0. Box 1625 \\ Idaho Falls, ID 83415 \\ K. V. Gilbert/P. G. Hagen \\ Rockwel1 International \\ Rocky Flats Plant \\ P. 0. Box 464 \\ Golden, CO 80401
}

G. W. Meyers

Atomics International Division

Rockwell International

8900 DeSoto Avenue

Canoga Park, CA 91304

T. H. Pigford

Department of Nuclear

Engineering

University of California

Berkeley, CA 94720

M. E. Spaeth

Science Applications, Inc.

2769 South Highland

Las Vegas, NV 89109

J. F. Strahl

Weston

2301 Research Boulevard

Third Floor

Rockville, MD 20850

R. Williams

Electric Power Research Inst itute

3412 Hillview Avenue

P.0. Box 10412

Palo Alto, CA 94304 
No. of

Copies

C. C. Chapman

West Valley Nuclear Services Company

P.0. Box 191

West Valley, NY 14171

J. C. Cwynar

West Valley Nuclear Services Company

P.0. Box 191

West Valley, NY 14171

L. R. Eisenstatt

West Valley Nuclear Services Company

P.0. Box 191

West Valley, NY 14171

J. L. Knabenschuh

West Valley Nuclear Services

Company

P.0. Box 191

West Valley, NY 14171

J. E. Krauss

West Valley Nuclear Services

Company

P.0. Box 191

West Valley, NY 14171

J. M. Pope

West Valley Nuclear Services Company

P.0. Box 191

West Valley, NY 14171

J. W. Bartlett

The Analytic Sciences

Corporation

6 Jacob Way

Reading, MA 01867

W. A. Freeby/J. L. Jardine

Bechtel National, Inc.

P.0. Box 3965

San Francisco, CA 94119
No. of

Copies

Librarian

Westinghouse Electric

Corporation

Technical Library

P.0. Box 40039

Albuquerque, NM 87196

L. L. Hench

Department of Materials Science $\&$ Engineering

University of Florida

Gainesville, FL 32611

J. L. Larocca, Chairman

Energy Researcb \& Development Authority

Empire State Plaza

Albany, NY 12223

R. G. Post

College of Engineering

University of Arizona

Tueson, AZ 85721

K. Mckinley

Joint Integration office

Rockwell Hanford Operations

Box 3150

Albuquerque, NM 87190

M. Neal

Joint Integration office

Rockwell Hanford Operations

Box 3150

AIbuquerque, NM 87190

ONSITE

8 DOE Richland Operations Office

J. H. Anttonen

E. A. Bracken

P. A. Craig

J. L. Rhoades

M. W. Shupe

J. J. Sutey

J. D. White

N. T. Karagianos 
No. of

Copies

14 Rockwell Hanford Operations

B. N. Anderson

L. Fitch

K. A. Gasper

R. N. Gurley

N. W. Kirch

H. E. McGuire

0. E. McKinney

J. W. Patterson

R. 0. Prosser

J. H. Roecker

T. B. Venziano

D. D. Wodrich

R. J. Wojtasak

File Copy

UNC United Nuclear Industries

T. E. Dabrowski/W. J. Kyriazis

2 Westinghouse Hanford Company

R. E. Lerch

J. D. Watrous
No of

Copies

51 Pacific Northwest Laboratory

W. F. Bonner

J. L. Buelt (20)

H. C. Burkholder

J. R. Carrell

J. G. Carter

T. O. Chikalla

V. F. Fitzpatrick

J. E. Hansen

M. S. Hanson

J. H. Jarrett

D. E. Knowlton

L. T. Lakey/K. M. Harmon

J. M. Latkovich

R. C. Liikala

R. P. Marshall/W. R. Wiley/ D. B. Cearlock

J. L. McElroy

A. H. McMakin

J. E. Minor

I. C. Nelson/J. G. Stephan

K. H. Oma

A. M. Platt/R. E. Nightingale

J. M. Rusin

D. J. Silviera

S. L. Stein

C. L. Timmerman

Technical Information (5)

Publishing Coordination (2) 